\title{
ДАНИЦА ГЛОЪОВИЋ
}

Универзитет Сингидунум,

Факултет за медије и комуникације, Београд

DOI 10.5937/kultura1860350G

УДК 659.123:791.641.3(73)"198/..." 659.131.7:316.774(73)"198/..."

стручни рад

\section{ИНTЕРТЕКСТУАЛНОСТИ ПРИПОВЕВАНКЕ ТЕХИИКЕУ PEKЛАМИ 3А MEKИHTOШ 1984}

Сажетак: У раду се представља интертекстуална структура наратива рекламе, која се уз појаву Мекинтоша сматра културним феноменом и естетском одредницом двадесетог века која и данас управља савременом културом. Еплова реклама за Мекинтош „1984”, у режсиј Ридлија Скота (Ridley Scott), подстакнута ригидним дискурсом тржишта персоналних рачунара тог времена, реферира на Орвелову класичну фикиију под истим називом. Поред вербалне интертекстуалности, у реклами су заступьене и визуелне референие које ће такође бити обухваћене овим радом. Приповедачка техника овог једноминутног видео спота активира парадигме просторне кохерентности и субверзије које су повезане са утопијским и дистопијским конструкиијама, чиме успешно управља простором и тренутком појаве Мекинтоша на тржишту. Систем јединствености који се у потпуности оријентисао на производњу по мери потрошача да би стекао профит, подразумева креирање комериијалног простора у коме се друштвени однос између индивидуалног и периипираног успоставља путем употребе и потрошње електронских производа и услуга. Овај нови вид комфора себе открива као облик робног фетишизма, ито би, као референиа на Маркса, био још један ниво вербалне интертекстуалности. Из колекиије технолошких делова и сировина, Мекинтош се мењь у ,, фантастичну форму” где физичка својства изражавају друштвено понашање. На овај начин, роба изражсава нешто друго осим суме юених сировина или радне снаге потребне за израду. Овим иновативним маркетиниким приступом кроз идеју 


\section{ДАНИЦА ГЛОЪОВИЋ}

ослобођења, информатички дискурс се трансформите. Свет многобројних и разноврсних информација супротставља се тоталитарним режимима - искуства потрошача и снага информаиије биће оно што влада светом. Представљањем овако иновативне маркетиншке стратегије са акиентом на приповедачке праксе успоставља се нова парадигма комодификаиије кроз кониепт индивидуалности и побуне против тоталитарног режима.

Кључне речи: Мекинтош рачунар, Интертекстуалност, Наратив, Приповедачке праксе, Маркетинг, Епл, ИБМ

\section{Увод}

Овај рад представља анализу интертекстуалне структуре наратива рекламе за Мекинтош коју је Манович (Lev Manovich), у једном од својих текстова, назвао културним феноменом и естетском одредницом двадесетог века која и данас управља савременом културом, док бих сама ову рекламу назвала ғы ејu (new age) месијанском. Монохроматски приказ колона беживотних мушкараца који се крећу скученим тунелима, праћени резонантним звуцима и гласом човека са екрана, није нешто што се до тада практиковало у маркетиншким рекламама за технолошке производе.

На самом почетку подсетићу на значење речи интертекстуалност. Кристева (Julia Kristeva), текст је дефинисала као „транслингвистички апарат који редистрибуира језички ред тако да успоставља релације између речи у комуникацији [...] Однос текста и интертекстуалности су нешто активно, стваралачко [...] Интертекстуална функција коју у „материјализованом" облику можемо да читамо на разним структурним нивоима сваког текста, даје тексту његове историјске и социјалне координате”. Јуван (Marko Juvan) објашњава да интертекстуалност омогућава „фиксацију граница међу текстовима, а тиме и рефлексију разлике између свога властитога и другог, прошлог и садашњег изражавања.” У складу са тим у фокусу овог рада, у односу на претходне анализе, биће просторно-временски елементи рекламе.

\section{Компјутерски свет 1984. године}

Еплова реклама за Мекинтош „1984”, у режији Ридлија Скота (Ridley Scott), представља прекретницу у поимању персоналних рачунара и њихове дотадашње улоге у друштву. Пре тога персонални рачунари нису представљали средство личног оснаживања и самодостигнућа. Подстакнута ригидним дискурсом конкуренције, ова реклама комуницира кроз уметнички аранжман слика који има своју унутрашњу логику. Представљала је наратив отпора на тржишту персоналних рачунара тог времена. У складу са тим, значајно је 


\section{ДАНИЦА ГЛОЪОВИЋ}

подсетити се и друштвено политичког тренутка у коме је реклама настала. Година 1984. била је изборна година у Сједињеним Америчким Државама, Роналд Реган (Ronald Reagan) однео је убедљиву победу над својим противкандидатима, чиме започиње свој други председнички мандат. У својој политичкој агенди, Реган не само да је подржавао развој високе технологије у облику стратешког система одбране, већ је форсирао свој анти-велики програм владе. Имајући у виду да је реклама за Мекинтош приказана широј јавности у јануару 1984. године , што је такође и период предизборне кампање, увиђа се још једна алузија у теми рекламе.

На културном фронту 1984. године, објављен је роман научне фантастике Неуроманцер (Neuromancer) Вилијама Гибсона (William Gibson) у коме се устоличује термин сајбер простора (cyberspace) у области умрежених електронских комуникација, што је значајно допринело растућој сајбер култури из осамдесетих и деведестих година. Филм Терминатор такође је реализован 1984. године, у коме је свету представљен прототип киборга као савршеног зла, нељудског облика живота креираног доласком свести у рачунарске мреже. Значајна студија Шери Туркл (Sherry Turkle) Друго concmвo (The Second Self) говори о младим програмерима, објављена је такође 1984. године. Туркл у својој студији представља идеју да људи улажу духовност у своје пословање са рачунарима, па чак и дају заслуге самим рачунарима као независној интелигенцији.

Сара Стеин (Sarah Stein) у свом тексту истиче још један догађај из 1984. године. У медијском окружењу, дошло је до промене стратегије оглашавања која је означила покушај удружења америчких рекламних агенција да поново укључе гледаоце у своје маркетиншке праксе. Удружење покреће штампану кампању са слоганом „Оглашавање. Друга реч за слободу избора”. Овај слоган намеће питање: „Да ли оглашавање представља одраз друштва или је друштво одраз оглашавања?” Употреба фразе „слобода избора” одјекнула је краткорочном маркетиншком стратегијом која је за циљну групу имала независне жене као потрошаче. Удружење америчких рекламних агенција, поставило је сцену за неразумљиве и двосмислене, често забавне, рекламне наративе који су обузели робну културу до деведесетих година. Рекламна кампања из 1984. године одбацила је симболичку размену еквивалентности између гледаоца и идеалне робе укључивањем критике оглашавања у огласе, користећи очигледне елементе у комерцијалним наративима да „препознају" софистицираност гледаоца и рефлексивно осмишљавање конвенција које информишу рутинско читање огласа. 
Тржишно истраживање удружења утврдило је да је ова нова реклама веома ефикасна у хватању и држању пажње публике, што захтева од гледаоца дешифровање нејасне симболичке нарације а понекад чак и о ком производу је реч.

\section{Анализа рекламе}

Еплова реклама за Мекинтош пуштена је у јавност само једном за време паузе на утакмици националне фудбалске лиге у Америци, што јасно говори о њеном утицају и иновативности маркетиншких пракси Епла. Ова чињеница намеће питање зашто би се оваква реклама приказивала на утакмици, када садржајно нису повезане? Мочник, у својој књизи „Три теорије”, издваја предмет вере које интерпретатор приликом интерпретације исказа допушта као могуће и интерпелира у идеологију којој исказ припада." Овим се осветљава начин на који Еплова реклама и Орвелов роман разоткривају рад подсвесног, истовремено га обликују, обећањем ослобођења и самоеманципације. Ту се наратив о несвеном и подсвесном разоткрива сасвим јасно, у жанру маркетиншког оглашавања чије је неписано правило да се о несвесном не прича већ се на њега утиче. Оно што је, такође, битно јесте да постоје две сасвим различите циљне групе ове рекламе. Прва је она која о Орвелу не зна ништа и за које ова реклама функционише на традиционалан начин, будећи фантазије несвесног, а другој припадају они коjој је Орвелов роман познат, и који су у стању да читају све интертекстуалне референце рекламе, чиме Еплов производ постаје софистицирани и престижни бренд, питање естетског и духовног статуса као и питање културног елитизма. За обе ове групе постоје очигледности у реклами које позивају, интерпелирају субјекта. Реферишући на већ поменуту Орвелову класичну фикцију под истим називом “ 1984 “, приповедачка пракса овог једноминутног видео спота активира прадигме просторне кохерентности и субверзије које су повезане са утопијским и дистопијским конструкцијама друштва, чиме се успешно управља простором и тренутком појаве Мекинтоша на тржишту. Ефективност „1984” може се разумети само ако су претходно познати дискурзивни обрасци који се тиме активирају. Текстуални ангажман рекламе ставља „1984”, Орвелов дистопијски роман, у оквир специфичне наративне традиције која поставља одређена очекивања. Управо ова очекивања на крају помажу у одређивању како ће гледалац декодирати Еплову поруку везану за појаву Мекинтоша.

Ипак, ако се изместимо из преформативности визуелних догађаја утакмице и рекламе, раван на којој се ова два 
догађаја подударају, свакако је спектакл. У прилог томе казује и Деборова (Guy Debord) констатација да спектакл није колекција слика, већ да су то друштвени односи посредовани сликама. То је тренутак у коме се друштво уједињу$\mathrm{je}$, где пажња и свест конвергира, постајући тиме изоловано са одређеним разлогом и циљем. Са оваквом поставком ствари, лако се долази до закључка да је управо спектакл био средство интерпелације у Еплову идеологију. Велики број људи, окупљен на једном месту, са емотивним набојем које једна утакмица носи, са жељом за борбу и вером у победу, је оно што је Еплу било потребно да се успостави оваква врста дискурзивне размене. Алтисеров концепт идеолошке интерпелације, конститутивни је елемент у формирању како субјективности тако и друштва у целини. Интерпелација је та која људским субјектима даје њихову суштину, односно капацитет да делују унутар друштва.

Идеали које данас повезујемо са персоналним рачунарима нису резултат технолошког детерминизма, већ су последица надметања међу групама различитих визија о томе шта рачунари могу и треба да чине. У складу са тим, нека од питања која се намећу овој теми су свакако и како се потрошачки производ афирмише и оснажује кроз поруку побуне и отпора конвенцији? Какву политичку визију подразумева обећање дато у овој реклами? Реклама „1984” иронијом промовисања индивидуалног ослобађања путем куповине предмета масовне производње, успоставила је оквир којим је међу корисницима креиран осећај за Мекинтош, додајући му ауру побуне и оснаживања. Епл је представио рачунар као алат за лично оснаживање и ослобађање. Систем јединствености који се у потпуности оријентише на производњу по мери потрошача ради стицања профита, подразумева креирање комерцијалног простора у коме се друштвени однос између индивидуалног и перципираног успоставља путем употребе и потрошње електронских производа и услуга. Овај нови вид комфора себе открива као облик робног фетишизма, препознаје се као референца на Маркса (Karl Marx), још један је ниво вербалне интертекстуалности. Како Маркс објашњава у Капиталу, роба може привући функције изван представљања употребе, рада и размене вредности. Из колекције технолошких делова и сировина, Мекинтош се мења у фантастичну форму где физичка својства изражавају друштвено понашање. На овај начин, роба изражава нешто друго осим суме њених сировина или радне снаге потребне за израду. Уместо тога, роба садржи вредност која је изнад само физичких и представља друштвене односе, како Маркс објашњава: 
„Тајанственост робног облика, састоји се просто у томе што он људима друштвене карактере властитог рада одражава као карактере који објективно припадају самим производима рада, као друштвена својства која те ствари имају од природе, а отуда им и друштвени однос произвођача према целокупном раду одражава као друштвен однос који изван њих постоји међу предметима. Овим quid pro quo (замењивањем) производи рада постају робе, чулно натчулне или друштвене ствари. Тако се и светлосни утисак неке ствари на нерв вида не показује као субјективан надражај самог нерва вида, већ као објективан облик ствари изван ока.”

Пре појаве Мекинтоша популарност личних рачунара кретала се у оквирима које је поставио Ај-би-ем (IBM), чији је циљ био повећање броја кадровских техничара. Стив Џобс (Steve Jobs) је увођењем термина „демократизација технологије" обећао да ће искористити моћ компјутера за појединца, што је за то време био потпуно нови маркетиншки приступ оријентисања према кориснику. Последица ове идеје указује и на промену саме интеракције човека и рачунара, чиме се уз развој интернета, фокус маркетиншких вештина усмерава на креирање садржаја, што приповедачку технику дефинише као једну од најбитнијих маркетиншких и менџерских алата модерног времена, претварајући причу у инструмент контроле . Маркетинг садржаја је стварање вредног, релевантног и упечатљивог садржаја од стране самог бренда/ компаније који се на доследан начин користи за генерисање позитивног понашања од стране купца или перспективе бренда. Неконвенционална реторичка стратегија „1984” била је нарочито прикладна за демаскирање идеологије врло конвенционалног, увијеног конкурента кроз формулацију контра-мита. У свом раду о историји персоналних рачунара Фрајдман (Ted Friedman) упозорава да је америчка јавност одавно била опрезна према компјутерима, сумњајући да је информациона технологија сила стандардизације, централизације и хијерархије.

За разлику од претходних рекламних кампања Епла, „1984” представља мање корисне и апстрактне аргументе у служби циљева продајних стратегија. Реклама почиње приказивањем сцена марширања колоне мушкараца кроз тунеле који су под надзором, док се у позадини чује наративни глас који наговештава заслуге времена које долази као „доба прочишћења информација". Комерцијално доследно и пажљиво наглашавају се оквири уског простора као места чисте идеологије како би се створио утисак скученог и затвореног простора. Звук који додатно доприноси сабласној атмосфери и скреће пажњу слушалаца, састоји се од комбинације дубоког 
упозоравајућег резонантног звука, звука марширајућих стопала и непрекидних електронских тонова. Учесници поворке су мушкарци обријаних глава, без изражајних лица, обучени у исте комбинезоне, чиме подсећају на затворске колоније, који дају снажан осећај на присилно понашање и доминанто веровање. Кадровима доминирају монохроматске сиве и плаве нијансе. Плава боја у овом контексту упућује на више значења. Поред тога што је то корпоративна боја Ај-би-ема, такође ствара утисак пасивности и самоће, немогућност за асертивно деловање. У својој књизи о моћи боја у визуелним приповедачким праксама Белантони (Pati Bellantoni) објашњава да плаво сиви тонови одају утисак меланхолије и пасивности, као и да плава боја суштински изражава беспомоћност. Штавише, овај тоталитаризам је означен и просторно. Као и са прототипним дистопијским текстовима, „1984” почиње изградњом изолованог места идеолошке униформности и топографије, а потом се појавом протагонисткиње овај простор подрива и омета, што се може означити као кључни тренутак промене парадигме.

Почетне секвенце рекламе, поред специфичног визуелног приповедања садрже и визуелну интертекстуалност која реферира на одређене секвенце 3мијског јајета, Бергмановог (Ingmar Bergman) филма у коме се приказује рађање фашизма. Почетне сцене у реклами, снимак марширања радника реферира на филм Фрица Ланга (Fritz Lang) из 1927. године, „Metropolis”. Филм приказује деструктивност капитализма и беду радничке класе у молби за саосећање и једнакост. Борбе моћи, питања сиромаштва, сукоба и страховања за будућност. Футуристички свет Метрополиса зависи од напредне технологије, у којој се крије тамна страна технолошког напретка у подземном граду. У бескрајним тунелима испод којих се налази велики град, приказане су мрачне сцене смрти механизованог индустријализма, где константни притисак на већу зараду и продуктивност корпоративног „Господара” доводи људе на ивицу уништења. Метрополис почиње серијом снимака погнутих и експлоатисаних радника који се крећу кружним тунелом, директно цитираним у Мекинтош реклами, који их доводи до подземног града и машина чије их одржавање убија. У истој реклами, сала у којој се радници скупљају, где се налази приказ главе на екрану архитектурално одражава главну зграду репресивног господара у Метрополису. Орвелов наратив пројектује немогућност промене у тоталитарној држави 1984. Лангов наратив допушта отпор и редистрибуцију контроле, што је централна тема за индустријску агенду Мекинтош рекламе, као и њеног наратива. 
Јединствене сцене марширања прекида појава протагонисткиње пуног колора, непознате жене атлетске грађе која трчи са чекићем у руци, након чега се приказује дестинација марширајућих људи ка сали у којој се налази масиван екран на коме се приказује крупни план мушке главе, средовечног човека са наочарима, шупљим лицем и челичним погледом, што је један од филмских стереотипа тиранина психопате. Сала у коју поворка долази је, такође не толико пространа, у њој се осећа ограничење због високих зидова и стубова који ограничавају поглед гледаоца. У овим кадровима посебно се уочава наслеђе филмског редитеља Ридлија Скота кроз интерпретацију дистопијских простора. Слаба позиција камере и опструкција линије вида су алати који су карактеристични за Скотову визуелну представу у Alien-у и Bladerunner-y. На овај начин, Скотово искуство у превођењу дистопије на екран уписује 1984 у типичне дистопијске филмске просторе изолације. Фигура са екрана интонира у надмоћном и догматском стилу, анестезираној публици о ери прочишћених информација и успостављању контроле над рачунарима. Оно што се издваја као интересантно је сам одсјај екрана, који је у реклами плаве боје, што је са сигурношћу била намера јер су ЦРТ (CRT) екрани тог времена имали жућкаст одсјај. Овај визуелни детаљ такође упућује на корпоративне боје Ај-би-ема коме је због брзог раста комапније дат надимак „,big blue”, што представља асоцијацију да би човек са екрана могао репрезентовати представника Ај-би-ема. Овај сегмент рекламе идентичан је сегменту из Орвелове књиге 1984 где Голдштајн, измишљотина министарства истине, аутоматски производи страх. Фигура атлетичарке обучене у црвени шорц и белу мајицу, на којој се налази илустрација Мекинтоша, утрчава у салу, уводећи хаос у дисциплинарни систем, што изазива осећај непријатељства према било коме ко покуша да је заустави. Ово је тренутак када се тон рекламе мења из упозоравајућег у хостилан, што уз њен изглед и приказ у боји, уноси драматичан моменат у јединствену монотонију околине.

Појава жене која показује храброст, снагу и одлучност, особине које су углавном резервисане за мушкарце, подстиче идентификацију неопходну за конституисање субјекта. То је улога која резонира са још једним класичним америчким наративом, чија је инфилтрација евидентна и у реклами „1984”. То је улога Дороти у филму „Чаробњак из Оза”, што значајно доприноси трајној популарности огласа. Алузија на „Чаробњака из Оза” појављује се у неколико визуелних кодова у реклами. Плавокоса жена која трчи обучена у црвени шортс, у јаком је контрасту са замагљеним плавичастим тоновима осталих кадрова, представља паралелу 
са уласком Дороти у обојени Оз из монохроматских сцена Канзаса. Глас који допире са екрана подсећа на бестелесну главу „Чаробњака из Оза”. Чекић који разбија екран у Мекинтош реклами, одражава Тотоово откриће Френка Моргана иза завесе, откривајући виртуелност чаробњака и његове подвале. Када се цела фигура протагонисткиње прикаже у крупном плану јасно се уочава да носи црвену обућу, а лого Епла у дугиним бојама које осветљавају екран говоре нам да више нисмо у Канзасу. Вилијам Лич (William Leach), у једном од својих текстова, назива аутора „Чаробњака из Оза”, Френка Баума (Frank Baum), једним од најранијих твораца маштајућег живота потрошачког доба.

„Баум је био први значајан заступник естетског приказа робе широке потрошње и жестоко је веровао у врлине потрошње, као и врлине слободног времена, уздижући табуе о изражавању жеље."

Жена у „1984” Мекинтош реклами, значајна је фигура за разлику од приказа у каснијим технолошким рекламама. Она представља моћно тело способно да изврши план са великим ризиком, формулисан умом способним да одржи своју аутономију, слику која је пружила херојску наративну фигуру за идентификацију. Она једнако представља политичку фигуру, која је свесна репресивне моћи напредног капитализма и спремна је да користи реакциону тактику. Ригорозна обука њеног тела је знак протеста и недостатка покорних, подређених тела роботизованих маса корисника ДОC-a (DOS) . Епл је у то време задржао слику независног, анти-корпоративног, индивидуалистичког америчког предузетништва, а фигура тркача одражава тај културални мит. Она представља недодирљиво тело, које ремети простор, одговарајуће средство за храбри и независни ум.

Ови кадрови указују и на разлику између корисника Ај-биемових и Еплових производа увођењем збуњујуће сложености у доба информација, што ће се касније и устоличити кроз познати Еплов слоган „Мисли другачије” (Think different).

„Постоји лоша технологија, централизована, ауторитарна, која руши људски дух и контролише умове људи. Од те лоше технологије можемо ослободити добру технологију која ће бити независна и индивидуализована уз помоћ Мекинтоша."

Наративом отпора који се манифестује кроз лик атлетичарке, Епл драстично мења и циљну групу којој су њихови производи намењени. Оваква прерасподела карактера циљне групе означава степен до ког је Епл схватио потребу да направи истраживање за своје производе изван свог 


\section{ДАНИЦА ГЛОЪОВИЋ}

традиционалног тржишта. У свом истраживању Линда Скот (Linda Scott), описала је корисника Еплових производа као меки фокус реклама за меку продају чиме су Еплови производи били окарактерисани као производи дизајнирани за креативне људе, чији су живот и рад били интегрисани и нису били категоријски раздвојени као корисници Ај-биемових производа. Еплово истраживање представља потенцијалну базу са различитим порукама о томе коме су ти рачунари намењени. У класичној традицији реторике, као и у доброј рекламној пракси, очекује се да се етос формулише кроз предвиђање жеља публике. Комерцијална реторика je, заправо, комуникација „ти и ја”. Порука се упућује циљној групи чији је референтни узорак узет из демографских и психолошких података, а потом свесно замишљена као контролисан, поједностављен артефакт, апстрахован из хаоса свакодневних сензација комерцијалног еквивалента лажних читаоца.

Последње три сцене активности атлетичарке, односе се на поремећај изолованости дистопијског простора рекламе. Она се зауставља, замахује и баца чекић. Ови кадрови доводе до примарног субверзивног чина у 1984, ломљење екрана у сали и уништење изолације су не само заустављање преноса поруке Великог брата, већ такође представља преграду баријере дистопије како би поткопала идеолошки простор. Разбијање екрана, праћено је бљештавом експлозијом светлости која заслепљује гледаоце, и испуњава светлошћу мрачни и тамни дистопијски простор. Ваздух се великом силином враћа у простор и испуњава редове присутних како би их изложио ономе што лежи изван лика са екрана и баријера система. Осам секунди пре завршетка једноминутне рекламе, приповедач кратко помиње реч „Мекинтош” мирним тоном, уз тријумфални испис слогана: „24. јануара Епл Комјутерс ће представити Мекинтош. И видећете зашто 1984 неће бити као '1984'.” Оно што се налази на другој страни екрана, открива се гласовном поруком уз приказивање сјајног логотипа Епла у дугиним бојама. Ова појава боје, означава коначно уништавање дистопијског простора jep се његова најпросторнија филмска репрезентација може видети уништена. Прекривање великог екрана, прекида карантин дистопије и омогућава спољном свету да узурпира свој идеолошки простор.

\section{Закључак}

Еплов успех у промоцији Мекинтоша, не би био могућ без наратива који карактеришу дистопијску фантастику, јер би се статус производа претворио у статус за који предлаже 
да се уништи. Постајући популарни објекат, кредибилитет Епловог идеала постао би угрожен. Мекинтош не би могао постати убедљив симбол индивидуалности. Другим речима, Еплова употреба дистопијске поетике ствара комерцијални простор у коме се Мекинтош може појавити и несметано инфилтрирати у доминантне трендове на тржишту популарне културе. Овим иновативним маркетиншким приступом кроз идеју ослобођења, информатички дискурс се трансформише. Свет многобројних и разноврсних информација супротставља се тоталитарним режимима, искуства потрошача и снага информације биће оно што влада светом. Представљањем овако иновативне маркетиншке стратегије, са акцентом на приповедању, успоставља се нова парадигма комодификације кроз концепт индивидуалности и побуне против тоталитарног режима. У модерним временима политичке и маркетиншке приповедачке праксе у фокусу својих делатности имају употребу овакве врсте исказа, одатле се и јавила потреба за реактуелизовањем и истраживањем рекламе „1984” кроз савремени научно-теоријски дискурс.

Савремене Еплове рекламе и даље промовишу јачање индивидуе путем поседовања одређеног технолошког уређаја. Корисници Еплових уређаја представљјају се као супер хероји модерног времена. Као људи који мисле другачије, креативније, и који својим деловањем и активностима мењају свет око себе.

\section{ЛИТЕРАТУРА:}

Altiser, L. (2015) Ideologija i državni ideološki aparati, Beograd.

Bellantoni, P. (2005) If it's purple, someone's gonna die. The power of Color in Visaul Storytelling, Oxford: Oxford, Focal Press.

Debord, G. (1994) The Society of the Spectacle, Zone Books.

Friedman, T. (1997) Apple's 1984: The Introduction of the Macintosh in the Cultural History of Personal Computers, Society for the History of Technology Convention, Pasadena, California.

Jackall, R. and Hirota J. (2000) Image makers, Advertising, Public Relations and the Ethos of Advocacy, London: The University of Chicago Press.

Juvan, M. (2013) Intertekstualnost, Novi Sad: Akademska knjiga.

Leach, W. (1989) Strategists of Display and the Production of Desire, Consuming Visions: Accumulation and Display of Goods in America, 1880-1920, ed. Bronner, S. J., New York: W. W. Norton.

Manovič, L. (2015) Jezik novih medija, Beograd: Klio.

Lutz, W. (1989) Beyond Nineteen Eighty-Four Doublespeak in a PostOrwellian Age, National Council of Teachers of English. 


\section{ДАНИЦА ГЛОЪОВИЋ}

Marks, K. (1978) Kapital I tom, Beograd: Prosveta.

Močnik, R. (2003) Tri teorije - Institucija, Nacija, Država, Beograd: Centar za savremenu umetnost.

Orvel, Dž. (2016) Životinjska farma, Beograd: Kontrast.

Pulizzi, J. (2012) The Rise of Storytelling as the New Marketing, Springer Science+Business Media,

Salmon, K. (2008) Storytelling ili pričam ti priču, Beograd: Clio.

Scott, L. (2004) For the Rest of Us": A Reader-Oriented Interpretation of Apple's “1984” Commercial, Journal of Popular Culture, Popular Culture Association, Wiley.

Stein, S. The (2002) “1984” Macintosh Ad: Cinematic Icons and Constitutive Rhetoric in the Launch of a New Machine, Routledge: Quarterly Journal of Speech.

Van Den Berg, T. (2012) Nineteen Eighty-Four and “1984”: Apple's Use of Dystopian Poetics in iCommodification, Journal of Literature and Science.

\section{Вебографија:}

Reklama 1984 za Mekintoš - https:/www.youtube.com/ watch?v=2zfqw8nhUwA (Pristupljeno: februar 2018.)

Izbori u Sjedinjenim Američkim Državama održani su u novembru 1984. godine. Izvor: https://www.britannica.com/event/United-Statespresidential-election-of-1984 (Pristupljeno avgust. 2018) 


\title{
ДАНИЦА ГЛОЪОВИЋ
}

\author{
Danica Glođović \\ Singidunum University, Faculty for Media and Communications, Belgrade

\section{INTERTEXTUALITY AND NARRATIVE TECHNIQUES IN MACINTOSH ADVERTISING 1984}

\begin{abstract}
This paper presents the intertextual structure of an advertisement narrative, which, with the appearance of the Macintosh, is considered as a cultural phenomenon and an aesthetic determinant of the twentieth century that still defines modern culture. The Apple advertisement for the Macintosh "1984", directed by Ridley Scott and prompted by the rigid discourse of the PC market of the time, refers to the Orwell's fiction classic of the same title. In addition to verbal intertextuality, the advertisement also includes visual references that will be considered in this paper. The narrative technique of this one-minute video clip activates the paradigms of spatial coherence and subversions that are associated with utopian and dystopian constructs, thus successfully managing the space and the moment when the Macintosh emerged on the market. A system of uniqueness that is fully oriented to the production of customized consumers in order to gain profit implies creation of a commercial space in which social relationship between the individual and the perceived is established through use and consumption of electronic products and services. This new form of comfort reveals itself as a form of commodity fetishism, which, as a reference to Marx, would be another level of verbal intertextuality. From a collection of technological parts and raw materials, the Macintosh has changed into a "fantastic form" where physical properties express social behaviour. In this way, the commodity expresses something other than the mere sum of its raw materials or labour required for its production. With this innovative marketing approach, through the idea of liberation, information discourse is transformed. The world of numerous and diverse information is opposed to totalitarian regimes - consumer experiences and the power of information will be the force that rules the world. By presenting such an innovative marketing strategy with an emphasis on narrative practices, a new paradigm of commodification was established through the concept of individuality and rebellion against a totalitarian regime.
\end{abstract}

Key words: Macintosh computer, intertextuality, narrative, storyteling, marketing, Apple, IBM 